\title{
From platform to basin to swell: orbital control on sedimentary sequences in the Oxfordian, Spain
}

\author{
André Strasser, ${ }_{1}^{1}$ Marc Aurell, ${ }^{2}$ Beatriz Bádenas, ${ }^{2}$ Guillermo Meléndez ${ }^{2}$ and Sara Tomás ${ }^{3}$ \\ ${ }^{1}$ Department of Geosciences, Geology, University of Fribourg, 1700 Fribourg, Switzerland; ${ }^{2}$ Departamento Ciencias de la Tierra, Universidad \\ de Zaragoza, 50009 Zaragoza, Spain; ${ }^{3}$ Departament de Geoquimica, Petrologia i Prospecció Geologica, Universitat de Barcelona, 08028 \\ Barcelona, Spain
}

\begin{abstract}
Climatic, oceanographic and ecological changes that control the formation and deposition of sediment in shallow and deep depositional environments commonly occur with periodicities of a few 10000 years. Consequently, in order to interpret sedimentary sequences in the geological past, high time resolution is required. This is best obtained by cyclostratigraphy. Three sections have been studied in the Oxfordian of north-eastern Spain: one represents a shallow, siliciclastic-carbonate platform with repetitive subaerial exposures, one an intraplatform basin with sponge bioherms, and one a swell where iron ooids and
\end{abstract}

\begin{abstract}
glauconite formed. The platform section displays a well-defined stacking pattern of depositional sequences; the deeper-water sections are well dated by ammonites. The correlation between the three sections is a best-fit solution integrating biostratigraphy, sequence stratigraphy and cyclostratigraphy. It is concluded that the small-scale depositional sequences formed in tune with the 100-ka orbital eccentricity cycle. An additional factor was differential subsidence that ruled basin morphology.
\end{abstract}

\section{Introduction}

Factors controlling the formation of sedimentary sequences vary greatly depending on their palaeogeographical position. On platforms, sediment is furnished by carbonate-producing organisms and/or through input from the continent. It is common to observe deepening-shallowing facies evolutions, which define metre-scale depositional sequences (e.g. Jones and Desrochers, 1992). Sediment may accumulate into the intertidal or supratidal zones, and the sequences are in this case capped by tidal-flat facies or palaeosols. Consequently, relative sea-level fluctuations can easily be interpreted from the facies trends. In deeper depositional environments, sea-level changes are only indirectly recorded (e.g. Einsele and Ricken, 1991; Osleger, 1991). For example, increased siliciclastic input may indicate increased erosion of the hinterland during a sea-level fall, or the presence and absence of tempestites may indicate fluctuations of the storm-wave base that follow sea-level fluctuations. However, continental run-off and storm intensity are also controlled by climatic changes. On

Correspondence: Dr André Strasser, Department of Geosciences, University of Fribourg, 1700 Fribourg, Switzerland. Tel.: 00412630089 78; fax: 00412630097 42; e-mail: andreas.strasser@unifr.ch swells, wave base and current regime are important factors influencing sediment distribution and accumulation.

In order to better understand how these factors are linked, it is useful to correlate the sedimentary sequences from one depositional environment to the other. A high time resolution is required because climatic, ecological and sea-level changes commonly occur on time-scales of a few thousand to a few 10000 years. This time resolution is best obtained by a cyclostratigraphic analysis of the sedimentary record. However, in order to constrain the cyclostratigraphy, the biostratigraphic and sequence-stratigraphic frame first needs to be established. Here we present a correlation of 100$\mathrm{ka}$ sequences in the Oxfordian of north-eastern Spain going from a shallow, mixed carbonate-siliciclastic platform to an intraplatform basin and to a swell, and we discuss the parameters that controlled the formation of these sequences.

\section{Palaeogeographical and stratigraphic setting}

In the Oxfordian (early Late Jurassic), the Basque-Cantabrian Basin was connected to the Iberian Basin by the Soria Seaway, a shallow carbonate platform (Fig. 1). Siliciclastics were furnished from land areas to the NE and SW of the seaway. In the Iberian Basin a shallow, temporarily exposed area known as the Montalbán-Ejulve Swell developed. This morphology was controlled by faulting and differential subsidence (Lardiés, 1990; Aurell et al., 2000, 2003).

For the present study, three sections have been selected (Fig. 1). The Aldealpozo section represents the shallow platform. It lies $2 \mathrm{~km}$ west of the village of Aldealpozo. The section starts along the road to Arancón and ends in the cut of the railway track. This section has been described by Dragastan et al. (1987) and Alonso and Mas (1990), and was interpreted in terms of sequence- and cyclostratigraphy by Pittet and Strasser (1998a). Ammonites are absent but its stratigraphic position in the Middle-Late Oxfordian is suggested by sequencestratigraphic reasoning (Aurell and Meléndez, 1993; Aurell et al., 1995). The section representing the intraplatform basin is found in a river bed approximately $5 \mathrm{~km} \mathrm{NNW}$ of the village of Ricla. It comprises the Yátova Formation and the lower and middle parts of the Sot de Chera Formation (Bádenas et al., 1998). The third section is situated in the canyon of Barranco de las Estacas approximately $3 \mathrm{~km}$ west of the village of Ariño and characterizes the sedimentary record on the Montalbán-Ejulve Swell. The biostratigraphy of these latter two sections is well established by ammonites at the level of subzone and biohorizon (Meléndez and 


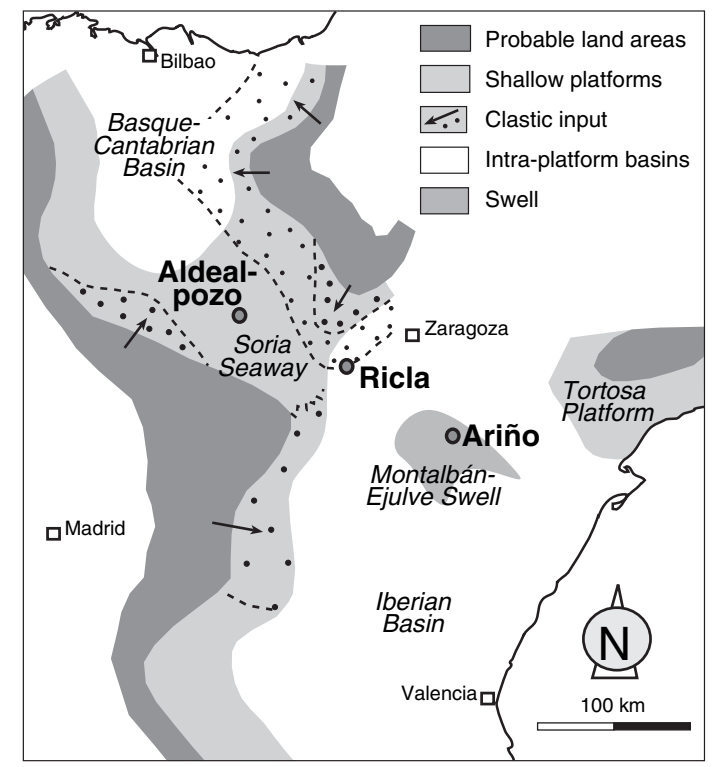

Fig. 1 Palaeogeography of the Middle-Late Oxfordian in northeastern Spain (modified from Aurell et al., 2003), and positioning of the three sections presented in this study.

Fontana, 1993; Meléndez et al., 1997; Pérez-Urresti et al., 1998).

\section{Definition of depositional sequences}

\section{Aldealpozo}

After subaerial exposure of most of the Soria Seaway at the Callovian-Oxfordian boundary, sedimentation recovered with a transgression at the Plicatilis-Transversarium boundary (Aurell and Meléndez, 1993). Facies and sedimentary structures indicate that the depositional environments included shallow lagoons with carbonate mud, peloids and oncoids, subtidal dunes with carbonate and/or siliciclastic grains, tidal flats with algal-microbial mats and birdseyes, and soils (Fig. 2). Well sorted, reddish-yellow sandstones with high-angle cross-bedding imply aeolian dunes (sequence 7 , Fig. 2). The individual beds are stacked into metre-scale sequences that commonly are capped by tidalflat facies or by palaeosols. In most cases, the facies evolution within these sequences displays a deepening, then shallowing trend. However, in several cases this trend is interrupted by emersion features on top of the individual beds (e.g. sequences 2 and 17, Fig. 2). At recurring intervals, there is a concentration of emersion features, and the sequences become very thin (e.g. sequences 18 to 20, Fig. 2). This hierarchical stacking pattern can be best explained by accommodation changes that were controlled by superimposed frequencies of sea-level fluctuations (Strasser et al., 1999). The top of the Aldealpozo Formation is interpreted to correspond to a sequence boundary situated in the Planula Zone (Aurell et al., 1995).

\section{Ricla}

The Ricla section commences with a condensed interval including frequent stratigraphic gaps and a condensed ammonite association including reelaborated specimens ranging in age from the latest Callovian (Lamberti Zone) to the early Middle Oxfordian (lower Plicatilis Zone; Aurell et al.,
1994). Then follow marl-limestone alternations that contain abundant sponges, tuberoids and microbial crusts (up to bed 70a, Fig. 2). Sponges are either preserved in the original upright position in wackestones, packstones or boundstones, or they are toppled and broken in marly floatstones. Larger sponge bioherms develop laterally to beds 20 and 28-30. Hexactinosan sponges are dominant and indicate low sedimentation rates in a relatively deep, open-marine environment (Pisera, 1991; Krautter, 1998). Ammonites, belemnites, planktonic foraminifera and brachiopods also testify to an open-marine environment. The surfaces of many limestone beds are irregular, locally bioturbated and impregnated by iron oxides. This suggests recurring time intervals when sedimentation rate was extremely reduced. According to these surfaces, depositional sequences can be defined (Fig. 2). They consist of 1-5 marl-limestone couplets. The distribution of ammonite subzones indicates that sedimentation rates were highly variable. An important facies change occurs above bed 70a (see also Fernández-López and Meléndez, 2004): quartz and also mica become abundant (some detrital quartz is already present in the beds below). The sandy limestones contain peloids and echinoderms; sponges are absent. Bed 100 is particular in that it contains solitary corals. The marl-limestone couplets are expanded and group into ill-defined bundles of four to seven couplets, which are interpreted as depositional sequences.

\section{Ariño}

At the base of the studied interval, the presence of iron ooids and reworked ammonites points to important condensation at the Callovian-Oxfordian boundary (Aurell et al., 1994). Ammonites of the Parandieri Subzone are found in bed 19. Sponges occur from bed 20 up to bed 27. Peloids are common. Bed 27 still contains sponges but already marks the facies change to

Fig. 2 Simplified logs of the three studied sections (outcrop profile and texture log; only the key facies elements are indicated). Note the change of scale between Aldealpozo and the other two sections. The biostratigraphy is based on ammonite subzones (oblique boundaries indicate uncertainty intervals). The morphology of the platform-slope transition in the inset is suggested in Aurell et al. (1995). Sequence- and cyclostratigraphic interpretation with correlation of inferred 400-ka sequence boundaries. For discussion refer to text. 

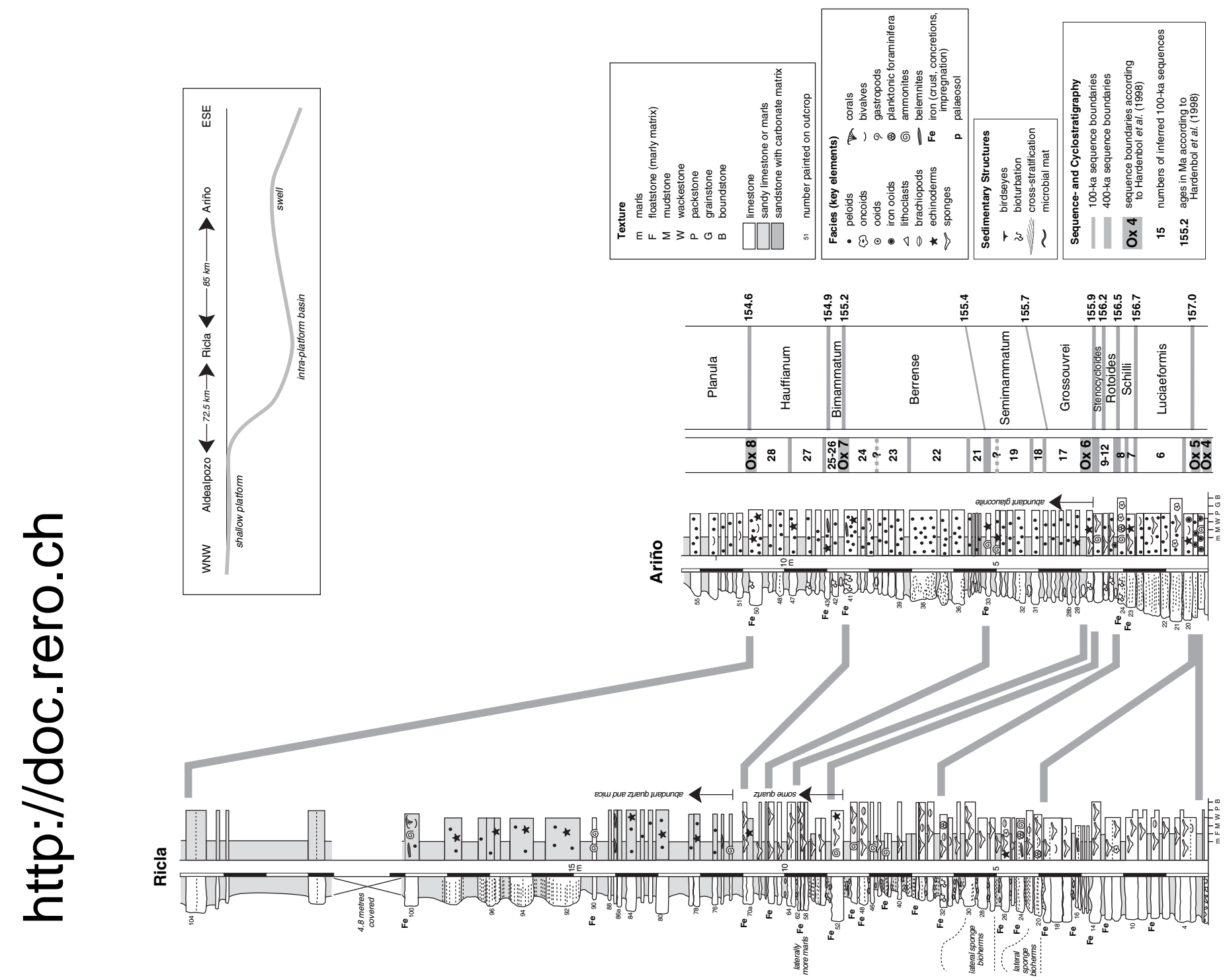

\begin{tabular}{|c|c|c|c|c|c|c|c|c|c|c|c|c|c|}
\hline ld & & unue!yneH & 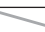 & unıетum & "!g & & 마이어 & & $! ! ! ! ! 4$ & & onf & ب⿻̣!puete & \\
\hline $\begin{array}{l} \\
x \\
0\end{array}$ & $\stackrel{\infty}{N}$ & $\hat{N}$ & $\stackrel{\mathscr{N}}{\pi}$ & $\stackrel{2}{ก}$ & 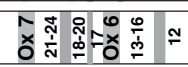 & $=$ & $\stackrel{\circ}{\circ}$ & $a$ & $\infty$ & $r$ & - n & 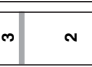 & $-\stackrel{0}{0}$ \\
\hline
\end{tabular}

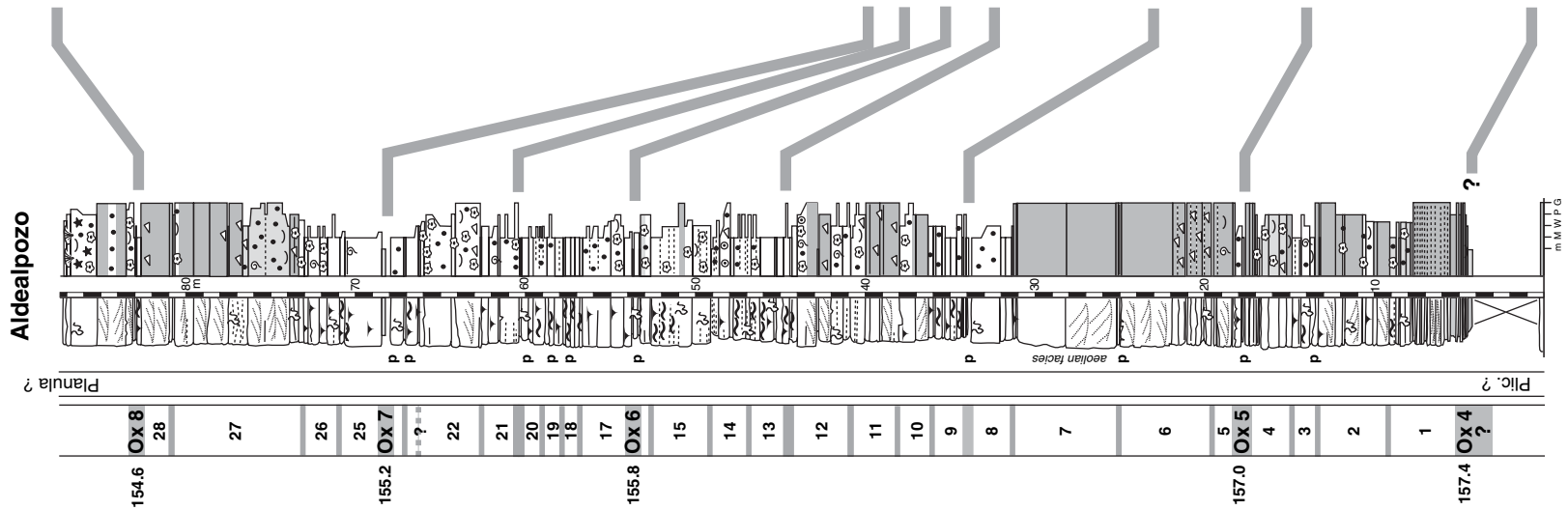


the upper part of the section. The limestone beds now are peloidal packstones to grainstones with abundant glauconite. Echinoderms and belemnites occur locally, ammonites are common. The depositional environment was fully marine as in Ricla, but energy was higher especially in the second part of the section. Glauconite suggests generally low sedimentation rates (Odin and Matter, 1981), and iron crusts on some bed surfaces indicate intervals of prolonged absence of sedimentation.

\section{Correlation}

The correlation between Ricla and Ariño is guided by the ammonite subzones (within the updated biostratigraphic framework of Cariou et al. 1991, and Meléndez and Fontana, 1993). In Aldealpozo, low accommodation and facies define important sequence boundaries, which are tentatively correlated with prominent surfaces in Ricla and Ariño (Table 1). According to their biostratigraphic position, several of these sequence boundaries are equivalent to boundaries identified in other European basins (Ox 4 to Ox 8; Hardenbol et al., 1998). The small-scale depositional sequences are numbered from 1 to 28 , as they have been identified in the most expanded section of Aldealpozo (Fig. 2).

\section{Discussion}

\section{Sequence- and cyclostratigraphy}

The detailed study of ammonites permits to establish a solid biostrati-

Table 1 Summary of sedimentological features used for correlation between the three sections. Condensation in Ricla and Ariño is indicated by reduced extension of ammonite subzones

\begin{tabular}{|c|c|c|c|}
\hline & Aldealpozo & Ricla & Ariño \\
\hline Sequence boundary $0 \times 8$ & $\begin{array}{l}\text { Tidal-flat facies on } \\
\text { top of subtidal dunes }\end{array}$ & Top of thick bed 104 & $\begin{array}{l}\text { Prominent surface on top of } \\
\text { bed } 50\end{array}$ \\
\hline Sequences 21-24 & $\begin{array}{l}\text { Accommodation increase } \\
\text { in sequences } 21 \text { and 22, } \\
\text { then rapid accommodation } \\
\text { loss with tidal flats and } \\
\text { palaeosols }\end{array}$ & $\begin{array}{l}\text { Condensed; sequences cannot } \\
\text { be defined }\end{array}$ & Thick sequence 22 \\
\hline Sequences 17-20 & $\begin{array}{l}\text { Lagoonal facies in sequence } \\
17, \text { then predominance of } \\
\text { tidal flats and palaeosols. } \\
\text { The upper part of this } \\
\text { interval suggests minimum } \\
\text { accommodation in the } \\
\text { Aldealpozo section }\end{array}$ & $\begin{array}{l}\text { Condensed; sequences cannot } \\
\text { be defined }\end{array}$ & $\begin{array}{l}\text { Expanded sedimentary record } \\
\text { but sequences difficult to } \\
\text { define. Prominent surface on } \\
\text { top of bed } 33 \text { may correspond } \\
\text { to minimum accommodation } \\
\text { in Aldealpozo }\end{array}$ \\
\hline Sequence boundary $0 \times 6$ & Erosion surface and palaeosol & $\begin{array}{l}\text { Iron-rich surface on top of bed } \\
62 \text { probably correlates with } \\
\text { palaeosol in Aldealpozo }\end{array}$ & $\begin{array}{l}\text { Top of limestone-dominated } \\
\text { interval }\end{array}$ \\
\hline Sequences 13-16 & $\begin{array}{l}\text { Predominant tidal-flat facies } \\
\text { in sequences } 13 \text { and } 14, \\
\text { lagoon in the lower part } \\
\text { of } 15\end{array}$ & $\begin{array}{l}\text { Condensed; sequences cannot } \\
\text { be defined }\end{array}$ & Strongly condensed \\
\hline Sequences 9-12 & $\begin{array}{l}\text { Tidal-flat facies in sequence } 9 \\
\text { and on top of } 12 \text {, lagoonal } \\
\text { facies in the central part } \\
\text { of this interval }\end{array}$ & $\begin{array}{l}\text { Predominant marls in sequences } \\
10 \text { and } 11 . \text { Prominent surface } \\
\text { on top of bed } 52 \text { may } \\
\text { correspond to tidal flats } \\
\text { in Aldealpozo }\end{array}$ & $\begin{array}{l}\text { Strongly condensed, with iron } \\
\text { ooids on top of bed } 24\end{array}$ \\
\hline Sequences $5-8$ & $\begin{array}{l}\text { Important accommodation } \\
\text { increase in sequences } \\
6 \text { and } 7 \text { (allowing preservation } \\
\text { of aeolian dunes). Palaeosol } \\
\text { on top of sequences } 6 \text { and } 8\end{array}$ & $\begin{array}{l}\text { Thickest sponge bioherms in } \\
\text { sequence } 7 \text {. Prominent surface } \\
\text { on top of bed } 32 \text { may } \\
\text { correspond to palaeosol } \\
\text { in Aldealpozo }\end{array}$ & $\begin{array}{l}\text { Thick sequence } 6 \text { but reduced } \\
\text { sequence } 7 \text {. Prominent surface } \\
\text { on top of bed } 24 \text { may } \\
\text { correspond to palaeosol } \\
\text { in Aldealpozo }\end{array}$ \\
\hline Sequence boundary $0 \times 5$ & Palaeosol & Prominent surface on top of bed 18 & Condensation surface \\
\hline Sequences 1-4 & $\begin{array}{l}\text { Accommodation increase in } \\
\text { sequences } 1 \text { and } 2 \text {, palaeosol } \\
\text { on top of } 2 \text {, thin sequence } 3\end{array}$ & $\begin{array}{l}\text { Thick sequences } 1 \text { and } 2 \text {. Prominent } \\
\text { Fe-encrusted surface on top of bed } \\
14 \text { may correspond to palaeosol in } \\
\text { Aldealpozo. Thin sequence } 3\end{array}$ & Condensed, with iron ooids \\
\hline Sequence boundary $0 \times 4$ & $?$ & Condensation surface & Condensation surface \\
\hline
\end{tabular}


graphic framework in the sections of Ricla and Ariño. However, condensation levels are common, and the definition of depositional sequences is not straightforward. On the other hand, the platform section of Aldealpozo exhibits a well-developed stacking pattern of depositional sequences: two to six individual beds group into metrescale sequences, and these in turn can be grouped into bundles of four. Prominent sequence boundaries are easy to identify because tidal flats and palaeosols indicate intertidal conditions or prolonged emersion. Furthermore, the metre-scale sequences commonly are thinner around these boundaries, indicating general loss of accommodation. However, biostratigraphic control is absent in Aldealpozo.

Through the best-fit correlation proposed in Fig. 2, the sequences defined in Aldealpozo can be traced into the deeper-water sections of Ricla and Ariño, and the biostratigraphic control there can be used to constrain the time frame in Aldealpozo. The ages proposed by Hardenbol et al. (1998) are calculated by interpolation between the absolute ages furnished by Gradstein et al. (1995). The Callovian-Oxfordian boundary is dated at $159.4 \pm 3.6 \mathrm{Ma}$, the OxfordianKimmeridgian boundary at $154.1 \pm$ 3.3 Ma, the values of 159.4 and 154.1, respectively, being the most probable ones. Accordingly, the interval between $\mathrm{Ox} 4$ and $\mathrm{Ox} 8$ covers c. $2.8 \mathrm{Ma}$ (Fig. 3) and comprises 28 sequences. It is therefore suggested that the depositional sequences correspond to the first eccentricity cycle of $100 \mathrm{ka}$ (Berger et al., 1989). The bundling of sequences into groups of four would then correspond to the second eccentricity cycle of $400 \mathrm{ka}$. The fact that several of the 400-ka sequence boundaries coincide with sequence boundaries also identified by Hardenbol et al. (1998) confirms the impression of Strasser et al. (2000) and Gale et al. (2002) that many third-order sequences (in the sense of Vail et al., 1991) have formed through sea-level changes that were in tune with the second eccentricity cycle. Expanded depositional sequences commonly contain four to six beds, which may be attributed to the precession cycle of $20 \mathrm{ka}$. However, autocyclic processes certainly were also active and created beds independently of sea-level fluctuations (Strasser, 1991).

Besides low- and high-frequency eustatic sea-level changes, also differential subsidence was an important factor in the formation of the observed sequences (Aurell et al., 2003). The thicknesses of the metre-scale

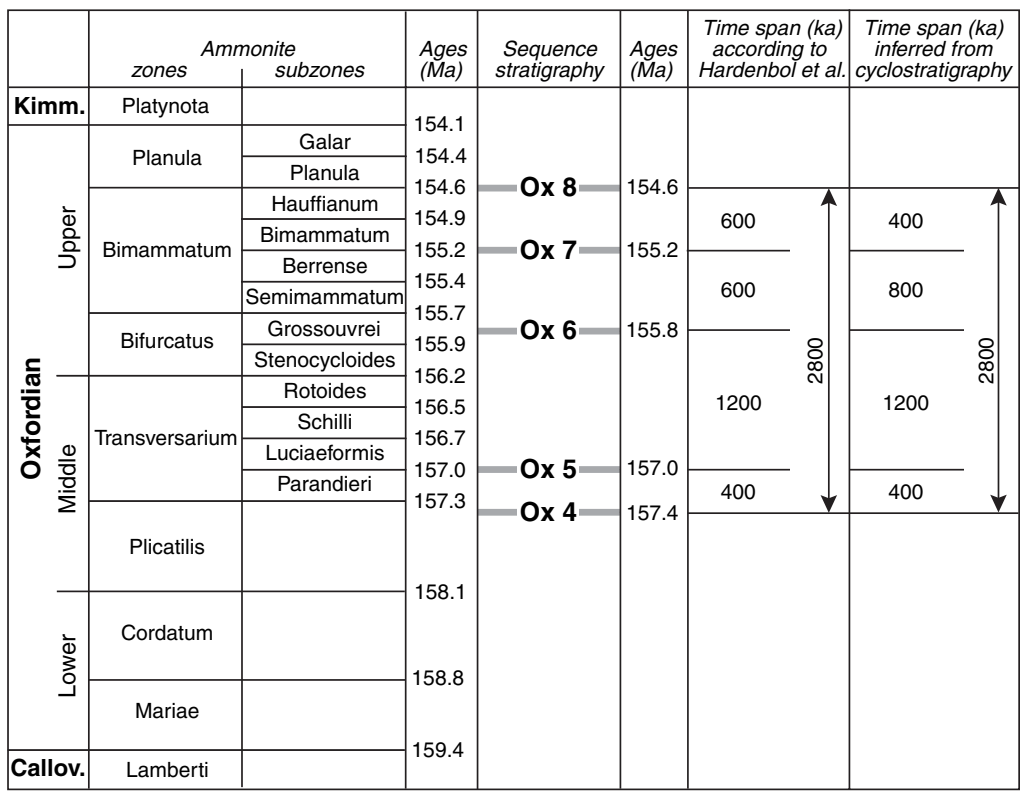

Fig. 3 Biostratigraphic and sequence-chronostratigraphic chart for the Oxfordian in Europe (based on Hardenbol et al., 1998). Ammonite subzones and sequence boundaries ( $\mathrm{Ox} 4$ to $\mathrm{Ox} 8$ ) are detailed only for the studied interval. sequences on the shallow platform (even if decompacted) do not always correspond to the accommodation changes expected for exclusively orbitally controlled sea-level fluctuations. It is therefore assumed that changes in subsidence rate influenced accommodation. In the sections of Ricla and Ariño, the condensed sequences do not necessarily appear at the same time (Fig. 2). This again implies synsedimentary tectonic activity that controlled the morphology of the intraplatform basin. However, sediment starvation relies not only on by-pass situations due to basin morphology but also on the production and distribution of the sediment itself.

\section{Formation of depositional sequences}

Orbitally controlled climate changes translate into sea-level changes, fluctuations of rainfall controlling continental run-off of siliciclastics and nutrients, changes in oceanic circulation patterns and upwelling, and planktonic productivity changes (Plint et al., 1992; Strasser et al., 1999). In several metre-scale sequences of the Aldealpozo section detrital quartz appears at the base and/or in the middle of the sequences, i.e. in the transgressive and/or maximum-flooding intervals (e.g. sequences 10, 11, 12 and 15; Fig. 2). This implies that climate was less humid when sea level was low and more humid during transgression and maximum flooding (Pittet and Strasser, 1998a). In addition, generalized input of detrital quartz in the lower part of the Aldealpozo section and above Ox 7 in Aldealpozo and Ricla is probably related to the progradation of siliciclastic aprons from the hinterland (Fig. 1; Aurell et al., 2003).

In Fig. 4, two sequences have been chosen as examples. Sequence 8 in Aldealpozo exhibits two thin beds of lagoonal facies overlying a tidal flat with birdseyes. They are interpreted as transgressive deposits. After the maximum flooding, the increased accommodation space is filled in by lagoonal facies. A sea-level drop below the sediment surface then creates a palaeosol, defining the sequence boundary. The three beds may represent three 20-ka precession cycles. The record of the two other $20-\mathrm{ka}$ cycles that make up the 100-ka cycle is missing at the 
Aldealpozo

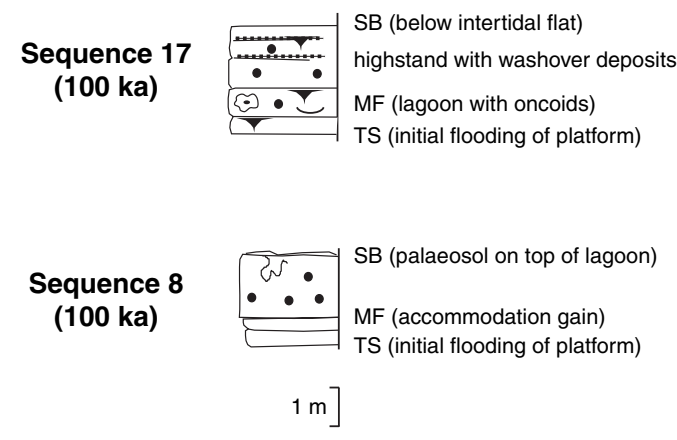

Ricla
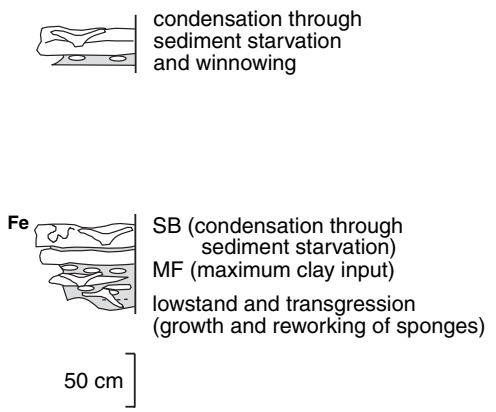

Ariño
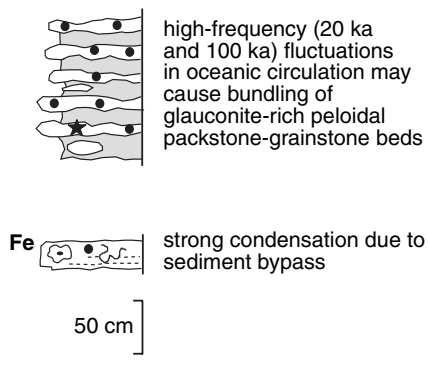

Fig. 4 Interpretations of two selected 100-ka sequences in the three studied sections. For discussion refer to text. For position in sections and symbols see Fig. 2. TS, transgressive surface; MF, maximum flooding; SB, sequence boundary.

base and/or at the top of the sequence. In Ricla, sponges grow on the sea floor. Clays are mobilized in the hinterland and exported to the basin during sea-level rise. Periodic storms topple and break the sponges. When sea level rises also the storm-wave base rises (or the concomitant climate change produces less storms). Around maximum flooding and during sealevel highstand, the carbonate factory on the platform is active and carbonate mud is exported to the basin (Schlager et al., 1994; Pittet and Strasser, 1998b), creating limestone beds in the basin. For the Kimmeridgian of the same area, Bádenas and Aurell (2002) have demonstrated the causal relationship between shallow carbonate production areas, export by storms, and accumulation on the ramp. When sea level drops, the platform is subaerially exposed and the climate less humid. Consequently, there is sediment starvation in the basin, and an iron-encrusted surface forms. It is possible that the formation of the carbonate lens and the two limestone beds was controlled by the 20-ka precession cycle. However, as in Aldealpozo, it is not possible to say how much time is missing at the base and at the top of the sequence. In Ariño, sequence 8 consists of one bed of oncoidal boundstone. This strong condensation may be related to the topographical position on a swell where sediment bypassed.

Sequence 17 in Aldealpozo displays five beds of lagoonal facies, three of which terminate with birds eyes indicating intertidal conditions (Fig. 4). It is tempting to attribute these beds to the record of five 20-ka precession cycles making up one 100-ka eccentricity cycle. The maximum flooding is placed in the bed where oncoids and bivalves are abundant. The contemporary sequence in Ricla contains sponges but is strongly condensed. A possible interpretation is that the generally low accommodation on the platform (sequences 16 and 18 to 20) forestalled carbonate export to the basin, although a short transgressive pulse allowed for deposition of the relatively thick sequence 17 in Aldealpozo. Also clay export was low because there was generally less rainfall. In Ariño, sequence 17 is interpreted to correspond to five marl-limestone couplets. Their interpretation is difficult: clays are present although the overall climate was less humid than during the deposition of the limestone-dominated sequences below. The abundant glauconite grains suggests low sedimentation rate; the packstone-grainstone texture and the broken but well-sorted bioclasts indicate current transport and/ or winnowing by waves. It is therefore possible that current speed waxed and waned, and/or wave base fell and rose, in tune with orbital cyclicity to produce the observed marl-limestone alternations.

\section{Conclusions}

The biostratigraphic, sequence-stratigraphic and cyclostratigraphic analysis of the three studied sections representing three different depositional environments has led to a high-resolution correlation of individ- ual sequences. It is implied that the observed small-scale sequences formed in tune with the 100-ka orbital eccentricity cycle. This high time-resolution allows for a discussion of the factors leading to the formation of these sequences: sea-level changes controlled accommodation on the platform and - together with climate - the carbonate factory. Carbonate mud was exported from the platform to the basin during maximum flooding and sea-level highstands, whereas lowstands commonly led to sediment starvation in the deeper water. Input of siliciclastics was steered by highfrequency climate changes and also by long-term progradation of siliciclastics from the hinterland. Fluctuations in current regime and storm wave base were in tune with the orbital cycles. Last but not least, long-term accommodation changes and basin morphology were strongly influenced by differential subsidence.

\section{Acknowledgements}

AS thanks the Swiss National Science Foundation (project No. 20-67736.02) for financial support. The other authors acknowledge the financial support by M.C.Y.T. Spain (Projects BTE2002-04453 and BTE2000-1148) and by the Aragón Government (Financiación de Grupos Emergentes). We thank Pascal Kindler and Bernard Pittet as well as associate editor Georges Gorin for their constructive reviews.

\section{References}

Alonso, A. and Mas, R., 1990. El Jurásico superior marino en el sector Demanda- 
Cameros (La Rioja-Soria). Cuad. Geología Ibérica, 14, 173-198.

Aurell, M. and Meléndez, A., 1993. Sedimentary evolution and sequence stratigraphy of the Upper Jurassic in the Central Iberian Chain, northeast Spain. Spec. Publ. Int. Ass. Sedimentol., 18, 343-368.

Aurell, M., Fernández-López, S. and Meléndez, G., 1994. The Middle-Upper Jurassic oolitic ironstone level in the Iberian Range (Spain). Eustatic implications. Geobios, 17, 549-561.

Aurell, M., Bosence, D.W.J. and Waltham, D.A., 1995. Carbonate ramp depositional systems from a late Jurassic epeiric platform (Iberian basin, Spain): a combined computer modelling and outcrop analysis. Sedimentology, 42, 75-94.

Aurell, M., Meléndez, G., Bádenas, B., Pérez-Urresti, I. and Ramajo, J., 2000. Sequence stratigraphy of the CallovianBerriasian (Middle Jurassic - Lower Cretaceous) of the Iberian Basin (NE Spain). GeoRes. Forum, 6, 281-292.

Aurell, M., Robles, S., Bádenas, B., Rosales, I., Quesada, S., Meléndez, G. and García-Ramos, J.C., 2003. Transgressive-regressive cycles and Jurassic palaeogeography of northeast Iberia. Sed. Geol., 162, 239-271.

Bádenas, B. and Aurell, M., 2002. Proximal-distal facies relationships and sedimentary processes in a storm dominated carbonate ramp (Kimmeridgian, northwest of the Iberian Ranges, Spain). Sed. Geol., 139, 319-340.

Bádenas, B., Aurell, M., Pérez-Urresti, I. and Delvene, G., 1998. Estratigrafia y evolución sedimentaria del Oxfordiense superior-Titónico inferior en Ricla (Zaragoza). Geogaceta, 24, 35-38.

Berger, A., Loutre, M.F. and Dehant, V., 1989. Astronomical frequencies for preQuaternary palaeoclimate studies. Terra Nova, 1, 474-479.

Cariou, E., Meléndez, G. and Branger, P., 1991. Définition d'une échelle biochronologique fine pour une zone d'ammonites de l'Oxfordien moyen: zone à Transversarium (province subméditerranéenne). C.R. Acad. Sci. Paris, 313 703-708.

Dragastan, O., Mensink, H., Mertmann, D. and Wilde, S., 1987. Küstennahe Sedimentationszyklen im Ober-Jura der westlichen Madero, Nord-Spanien. N. Jb. Geol. Paläontol., 175, 377-398.

Einsele, G. and Ricken, W., 1991. Limestone-marl alternation - an overview. In: Cycles and Events in Stratigraphy (G. Einsele, W. Ricken and A. Seilacher, eds), pp. 23-47. Springer-Verlag, Berlin.
Fernández-López, S.R. and Meléndez, G., 2004. Fossilization of ammonites and sedimentary events in deep environments of carbonate platform (highest Middle to lowest Upper Oxfordian, Spain). Riv. Italiana Paleontologia e Stratigrafia, 110, 219-230.

Gale, A.S., Hardenbol, J., Hathway, B., Kennedy, W.J., Young, J.R. and Phansalkar, V., 2002. Global correlation of Cenomanian (Upper Cretaceous) sequences: evidence for Milankovitch control on sea level. Geology, 30, 291-294.

Gradstein, F.M., Agterberg, F.P., Ogg, J.G., Hardenbol, J., van Veen, P., Thierry, J. and Huang, Z., 1995. A Triassic, Jurassic and Cretaceous time scale. In: Geochronology, Time Scales and Global Stratigraphic Correlation (W.A. Berggren, D.V. Kent, M.P. Aubry and J. Hardenbol, eds), Soc. Sed. Geol. Spec. Publ., 54, 95-126.

Hardenbol, J., Thierry, J., Farley, M.B., Jacquin, T., De Graciansky, P.-C. and Vail, P.R., 1998. Charts. In: Mesozoic and Cenozoic Sequence Stratigraphy of European Basins (P.-C. De Graciansky J., Hardenbol T., Jacquin and P.R. Vail, eds). Soc. Sed. Geol. Spec. Publ., 60.

Jones, B. and Desrochers, A., 1992. Shallow carbonate platforms. In: Facies Models Response to Sea Level Change (R.G. Walker and N.P. James, eds), pp. 277301. Geological Association, Canada.

Krautter, M., 1998. Ecology of siliceous sponges - application to the environmental interpretation of the Upper Jurassic sponge facies (Oxfordian) of Spain. Cuad. Geología Ibérica, 24, 223-239.

Lardiés, M.D., 1990. Observaciones bioestratigráficas y sedimentológicas sobre el Calloviense en la Provincia de Zaragoza. Cuad. Geol. Ibérica, 14, 157-172.

Meléndez, G. and Fontana, B., 1993. Biostratigraphic correlation of the Middle Oxfordian sediments in the Iberian Chain, eastern Spain. Acta Geol. Pol., 43, 193-211.

Meléndez, G., Bello, J., Delvene, G. and Pérez-Urresti, I., 1997. El Jurásico Medio y Superior (Calloviense-Kimmeridgiense) en el sector de la Llanura de Arcos (Ariño-Oliete, Teruel): análisis tafonómico y bioestratigrafía. Cuad. Geol. Ibérica, 23, 269-300.

Odin, G.S. and Matter, A., 1981. De glauconiarum origine. Sedimentology, 28, 611-641.

Osleger, D., 1991. Subtidal carbonate cycles: implications for allocyclic vs autocyclic controls. Geology, 19, 917-920.

Pérez-Urresti, I., Delvene, G., Meléndez, G. and Ramajo, J., 1998. El Oxfordiense
Superior y la posición del límite Oxfordiense-Kimmeridgiense en el sector de Tosos-Aguilón (Rama Aragonesa de la Cordillera Ibérica, España). Geogaceta, 24, 251-254.

Pisera, A., 1991. Upper Jurassic sponge megafacies in Spain: preliminary report. In: Fossil and Recent Sponges (J. Reitner and H. Keupp, eds), pp. 468-497. Springer-Verlag, Berlin.

Pittet, B. and Strasser, A., 1998a. Longdistance correlations by sequence stratigraphy and cyclostratigraphy: examples and implications (Oxfordian from the Swiss Jura, Spain, and Normandy). Geol. Rundschau, 86, 852-874.

Pittet, B. and Strasser, A., 1998b. Depositional sequences in deep-shelf environments formed through carbonate-mud import from the shallow platform (Late Oxfordian, German Swabian Alb and eastern Swiss Jura). Eclogae Geol. Helv., 91, 149-169.

Plint, A.G., Eyles, N., Eyles, C.H. and Walker, R.G., 1992. Control of sea level change. In: Facies Models - Response to Sea Level Change (R.G. Walker and N.P. James, eds), pp. 15-25. Geological Association, Canada.

Schlager, W., Reijmer, J.J.G. and Droxler, A., 1994. Highstand shedding of carbonate platforms. J. Sed. Res., B64, 270-281.

Strasser, A., 1991. Lagoonal-peritidal sequences in carbonate environments: autocyclic and allocyclic processes. In: Cycles and Events in Stratigraphy (G. Einsele, W. Ricken and A. Seilacher, eds), pp. 709-721. Springer-Verlag, Berlin.

Strasser, A., Pittet, B., Hillgärtner, H. and Pasquier, J.-B., 1999. Depositional sequences in shallow carbonate-dominated sedimentary systems: concepts for a high-resolution analysis. Sed. Geol., 128, 201-221.

Strasser, A., Hillgärtner, H., Hug, W. and Pittet, B., 2000. Third-order depositional sequences reflecting Milankovitch cyclicity. Terra Nova, 12, 303-311.

Vail, P.R., Audemard, F., Bowman, S.A., Eisner, P.N. and Perez-Cruz, C., 1991. The stratigraphic signatures of tectonics, eustasy and sedimentology - an overview. In: Cycles and Events in Stratigraphy (G. Einsele, W. Ricken and A. Seilacher, eds), pp. 617-659. SpringerVerlag, Berlin. 